$14^{\text {th }}$ Conf. Agric. Develop. Res., Fac. of Agric., Ain Shams Univ., March, 2019, Cairo, Egypt

Special Issue, 27(1), 419 - 429, 2019

Website: http://strategy-plan.asu.edu.eg/AUJASCI/

\title{
EFFECT OF SPIRULIN (ARTHROSPIRA PLATENSIS) A AND NANNO- CHLOROPSIS (NANNOCHLOROPSIS GADITANA) SUPPLEMENTATION ON GROWTH PERFORMANCE, FEED UTILIZATION AND CARCASS COMPOSITION OF NILE TILAPIA (Oreochromis niloticus)
}

\author{
Zeinab, M. A. Abd-El Azeem, Ali, T.A. and Osman, M.F. \\ Animal Production Dept., Fac. of Agric., Ain Shams Univ., P.O. Box 68-Hadyek Shoubra \\ 11241, Cairo, Egypt
}

*Corresponding author: zeinab_ma83@agr.asu.edu.eg

\section{ABSTRACT}

The study was carried out at Faculty of Agriculture, Ain Shams University to assess the effect of two of algae species (Arthrospira platensis and Nannochloropsis gaditana) on growth performance of monosex tilapia fish (Oreochromis niloticus), fish were fed on a basal diet supplemented with $0,3,5,7 \%$ of each algae. To perform seven experimental treatments were assigned in three replicates each. The experiment was designated as follows:

(T1) control (without algae), (T2) basal diet supplemented with $3 \%$ spirulina (spiru 3), (T3) basal diet supplemented with $5 \%$ spirulina (spiru 5), (T4) basal diet supplemented with $7 \%$ spirulina (spiru 7), (T5) basal diet supplemented with 3\% Nannochloropsis (nanno 3), (T6) basal diet supplemented with 5\% Nannochloropsis (nanno 5) and (T7) basal diet supplemented with 7\% Nannochloropsis (nanno 7). Experimental tanks were a part of closed recirculating system, where almost constant environmental conditions were kept throughout the experimental period. Twenty-one quadrate fiber glass tanks with 108-liter water capacity were stocked with 15 fish per tank. The individual initial body weight $(2.7 \mathrm{~g})$ was recorded at the beginning of the experiment. All fish in each tank was weighed every two weeks during the whole experimental period. The fish were fed the experimental diet for 95 days Results indicated that nanno 5 treatment had higher significant trend $(P<0.05)$ final body weight $(F B W)$, average weight
\end{abstract}

gain (AWG) and average daily gain (ADG) compared with the other experimental treatments. The best specific growth rate (SGR), feed conversion ratio (FCR) and feed efficiency ratio (FER) were found in nanno 7. Also, it was observed that spiru 7 have a high significant difference $(P<0.05)$ in protein efficiency ratio (PER) and protein productive value (PPV). On the other hand, the results showed that the lowest AWG, ADG and (FER) appeared in spiru $7 \%$. No mortality in nanno7 and spiru 7 . Finally, using of nano $5 \%$ or spiru $7 \%$ enhance growth performance and feeding in tilapia fish.

Key words: microalgae, (Arthrospira platensis) , Nannochloropsis gaditana, feed additive and tilapia.

\section{INTRODUCTION}

Microalgae play an important role in aquatic food chain and are popularly used in rearing of aquatic animals like mollusks, shrimps and fishes at different growth stages (Borowitzka 1988). They are required for larvae nutrition during a brief period of life cycle and are used either for direct consumption or indirectly as prepared feed. In most instances, the whole algae are used as feed or feed supplement. Data on chemical composition of algae give the basic information on the nutritive potential of the algae biomass (Brown et al 1997). The nutritional value of microalgae is influenced by their size, shape, digestibility, and biochemical 
compositions (Brown et al 1997). Most of these biomolecules are not produced in the ani$\mathrm{mal} /$ human body but termed as essential; therefore, it is highly recommended to make these biomolecules available for food and feed purposes. (Yaakob et al 2014)

Spirulina, Arthrospir platensis is a freshwater blue-green filamentous alga, and it is receiving increasing attention for its bioactive components such as vitamins (especially vitamin A and B12), minerals, polyunsaturated fatty acids, carotenes and other pigments that have antioxidants activity (Madhava et al 2000 and Lin et al 2007). It is also containing high protein contents (up to $70 \%$ on dry weight) and lipids (7-16\%) (Vonshak 1997). These nutritional elements make as a potential food items for persons suffering from coronary illness and obesity. (Arthrospira platensis) Spirulina is suitable for animal feeding (Cohen, 1997) and as supplement nutrients for humans (Qureshi et al 1995). In addition, (Arthrospira platensis) Spirulina is considered one of the most concentrated natural sources for nutrition to both terrestrial and aquatic animals. Therefore, Spirulina could be an excellent source of useful nutrients (Glombitza and Koh, 1989) as well as a good energy source that can be used as crucial component for animal feeding (Kishimoto et al 1994, Kim et al 2013).

Nannochloropsis gaditana represents a genus of marine microalgae with high photosynthetic efficiency and can convert carbon dioxide to storage lipids mainly in the form of triacylglycerols and to the $\omega-3$ long-chain polyunsaturated fatty acid eicosapentaenoic acid (EPA). Recently, Nannochloropsis gaditana has received ever-increasing interests of both research and public community (Xiao et al 2016) This microalga is an important food source and feed additive in the commercial rearing of many aquatic animals, especially live food organisms such as rotifers which, in turn, are used to rear the larvae of marine finfish. (Durmaz. 2007). The microalgal genus Nannochloropsis gaditana has been receiving ever-increasing research interest owing to its ability to synthesize not only neutral lipids for biodiesel production but also EPA for functional food (Hoffmann et a/2010 and Ma et al 2014).

The specific aim of the present study was to examine the effect of dietary supplemented with two species of microalgae ((Arthrospira platensis) Spirulina and Nannocholoropsis gaditana) with different levels on growth performance, feed utilization and carcass composition of Nile tilapia.

\section{MATERIALS AND METHODS}

Seven treatments with triplicates were carried out at Faculty of Agriculture, Ain Shams University to assess the effect of two types of algae ((Arthrospira platensis) Spirulina and -Nannochloropsis gaditana) on growth performance of monosex tilapia fish (Oreochromis niloticus) which supplemented in basal diet at $(3,5,7 \%)$ for each algae.

\section{The rearing system}

Twenty-one quadrate fiber glass tanks $60 \times 30$ $\times 60 \mathrm{~cm}$, width, depth, height, respectively, were used. During the experimental period the fish tanks were receiving a constant water supply from a header tank. In this system, the used water drained from the rearing tanks was piped into mechanical and biological filtration system and then returned to the fish tanks. Mechanical filtration and biological filtration carried out by screens and submersible media bags, respectively. The system was provided with a thermostatic water heater $(2.5 \mathrm{KW})$ to control temperature at desired levels. Rearing tanks were continuously aerated by air stones that were connected to air lines of a small air blower $(0.12 \mathrm{Hp})$.

\section{Algae}

Dried Arthrospira platensis (Spirulina) were obtained from phytoplankton laboratory, limnology department, Central Laboratory of Aquaculture Research; Agriculture Research Center: Egypt and dried Nannochloropsis gaditana (Nanochloropsis) were obtained from Biotechnology lab, National Research Council (NRC) Egypt. The two types of algae were supplemented to basal experimental diet at $(3,5,7 \%)$ for each alga. The chemical composition of these algae was shown in Table 1

Table. 1 Chemical composition of the two type of algae as dry matter basis

\begin{tabular}{|l|c|c|}
\hline & Spirulina & Nannochloropsis \\
\hline Dry matter (\%) & 90 & 90 \\
Crude protein (\%) & 43 & 17.5 \\
Crude fiber (\%) & 4 & 3 \\
Ether extract (\%) & 3.5 & 18 \\
Ash (\%) & 11 & 15 \\
NFE (\%) & 28.5 & 36.5 \\
\hline
\end{tabular}



composition of Nile tilapia (Oreochromis niloticus)

\section{Experimental diets}

The formulation of experimental diet shown in Tables 2. The chemical analyses of the experimental diets were carried out to estimate dry matter (DM), crude protein (CP), ether extracts (EE), crude fiber (CF) and ash according to the method described by A.O.A.C (1975). Amino acids of basel diet were calculated according to NRC (1993), spirulina according to Ogbonda et al (2007) and Nannochloropsis gaditana according to James et al (1984)

Fish in each tank were fed two times daily (six days a week) the seventh day, fish were fasted. The daily feed allowances were calculated according to fish metabolic body weight (Meyer-Bergdorf et al 1989) by using the following equation:

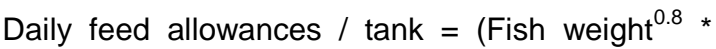
$1.7 \%$ * fish number.

To avoid changes in the chemical composition of fish diets, Arthrospira platensis and Nannochloropsis gaditana were used as feed additives to replace part of soybean meal and wheat middling, respectively.

\section{Fish sampling and nutritional criteria}

Fish fingerlings were obtained from World Fish Center located at El Shrkia Governorate. A total of 315 fish werje randomly distributed to 21 ponds, the individual initial body weight $(2.7 \mathrm{~g} \pm 0.095)$ was recorded at the beginning of the experiment. All fish in each tank was weighed every two weeks during the whole experimental period. According to the data of body weights, the following parameters were estimated: weight gain, average daily gain, specific growth rate and nutritional parameters were calculated according to Cho and Kaushik (1985) as following:

\section{Average weight gain (AWG)}

AWG $(g /$ fish $)=$ average final weight - average initial weight

\section{Average daily gain (ADG)}

Daily gain was estimated according to the following formula:

$$
A D G=\left(w t_{2}-w t_{1}\right) / t
$$

Where:

wt 1 = first fish weight in grams. wt 2 = following fish weight in grams.

$\mathrm{t}=$ period in day.

Specific growth rate (SGR \%/day)

$S G R=\left(\right.$ Ln wt $\left._{2}-\mathrm{Ln} \mathrm{wt}_{1}\right) \times 100 / \mathrm{t}$.

Where:

$\operatorname{Ln}=(\log 10 x)^{3.303}$

$\mathrm{t}=$ period in day

\section{Feed conversion ratio (FCR)}

The feed conversion ratio was calculated according to the following equation:

$$
\begin{aligned}
& \mathrm{FCR}=\frac{\text { Total feed consumption }(\mathrm{g})}{\text { Final body weight }(\mathrm{g}) \text { - initial body weight }(\mathrm{g})} \\
& \text { Feed efficiency ratio (FER) }
\end{aligned}
$$

The feed efficiency ratio was calculated according to the following equation:

\section{Protein efficiency ratio (PER)}

$$
F E R=\frac{\text { inalbody weight }(\mathrm{g}) \text { - initial body weight }(\mathrm{g})}{\text { Total } \mathrm{f} \text { eedconsumption }(\mathrm{g})}
$$

The protein efficiency ratio was calculated according to the following equation:

PER $=\frac{\text { Finalbody weight }(\mathrm{g})-\text { initialbody weight }(\mathrm{g})}{\text { proteinintake }(\mathrm{g})}$

Protein productive value $($ PPV) $=100$ [protein gain in fish $(\mathrm{g}) /$ protein intake in feed $(\mathrm{g})$ ];

\section{Survival rate}

Where:

$$
(\mathrm{Z} / \mathrm{X}) \mathrm{X} 100
$$

$\mathbf{Z}$ is surviving fish number

$\mathbf{X}$ is the initial fish number

\section{Statistical analysis:}

The statistical analysis was applied on the collected data according to Steel and Torrie (1980) using (SAS,2009), Differences between means were tested for significance according to Duncan's multiple rang test (Duncan, 1955).

$$
Y i j k=U+T i+D j+(T D)_{I J}+e_{i j k}
$$

Where:

Yij =observation. 
Table.2 Formulation of the experimental diets (\% dry matter bases).

\begin{tabular}{|c|c|c|c|c|c|c|c|}
\hline Ingredient (\%) & T1 & T2 & T3 & T4 & T5 & T6 & T7 \\
\hline Fish meal & 15 & 15 & 15 & 15 & 15 & 15 & 15 \\
\hline Soymeal 48 & 39 & 36 & 34 & 32 & 39 & 39 & 39 \\
\hline Wheat middling & 25 & 25 & 25 & 25 & 22 & 20 & 18 \\
\hline Rice bran & 7 & 7 & 7 & 7 & 7 & 7 & 7 \\
\hline Yellow corn & 9 & 9 & 9 & 9 & 9 & 9 & 9 \\
\hline Fish oil & 1 & 1 & 1 & 1 & 1 & 1 & 1 \\
\hline Plant oil & 1 & 1 & 1 & 1 & 1 & 1 & 1 \\
\hline Spirulina & 0 & 3 & 5 & 7 & 0 & 0 & 0 \\
\hline Nannochloropsis & 0 & 0 & 0 & 0 & 3 & 5 & 7 \\
\hline Salt & 1 & 1 & 1 & 1 & 1 & 1 & 1 \\
\hline Premix & 1 & 1 & 1 & 1 & 1 & 1 & 1 \\
\hline lime stone & 1 & 1 & 1 & 1 & 1 & 1 & 1 \\
\hline \multicolumn{8}{|c|}{ Chemical composition \% (DM bases) } \\
\hline Dry matter & 91.3 & 91.1 & 91.3 & 91.2 & 91.3 & 91.1 & 91.3 \\
\hline Protein & 34 & 33.8 & 33.7 & 33.6 & 34 & 34.1 & 34.1 \\
\hline Ether extract & 5.29 & 5.37 & 5.42 & 5.47 & 5.34 & 5.37 & 5.4 \\
\hline Crud fiber & 4.07 & 4.07 & 4.07 & 4.07 & 4.07 & 4.08 & 4.09 \\
\hline Ash & 10.37 & 10.46 & 10.75 & 11.08 & 11.29 & 11.76 & 12.69 \\
\hline NFE & 37.57 & 37.4 & 37.36 & 36.98 & 36.6 & 35.79 & 35.02 \\
\hline \multicolumn{8}{|c|}{ Calculated amino acid profile of the experimental diet } \\
\hline Arginine & 2.54 & 2.79 & 2.96 & 3.12 & 2.61 & 2.65 & 2.70 \\
\hline Histidine & 0.84 & 0.86 & 0.88 & 0.90 & 0.85 & 0.87 & 0.88 \\
\hline Isoleucine & 1.53 & 1.59 & 1.64 & 1.68 & 1.55 & 1.57 & 1.59 \\
\hline Leucine & 2.60 & 2.63 & 2.65 & 2.67 & 2.67 & 2.71 & 2.76 \\
\hline Lysine & 2.18 & 2.19 & 2.20 & 2.21 & 2.24 & 2.28 & 2.31 \\
\hline Methionine & 0.63 & 0.68 & 0.71 & 0.75 & 0.64 & 0.64 & 0.64 \\
\hline Cysteine & 0.48 & 0.48 & 0.48 & 0.48 & 0.49 & 0.49 & 0.49 \\
\hline Phenylalanine & 1.55 & 1.56 & 1.57 & 1.58 & 1.60 & 1.63 & 1.66 \\
\hline Threonine & 1.34 & 1.34 & 1.34 & 1.34 & 1.38 & 1.41 & 1.44 \\
\hline Tryptophan & 2.78 & 2.78 & 2.78 & 2.78 & 2.78 & 2.78 & 2.78 \\
\hline Tyrosine & 1.28 & 1.46 & 1.57 & 1.69 & 1.31 & 1.34 & 1.36 \\
\hline
\end{tabular}

$\mathrm{U}=$ the overall mean

$\mathrm{Ti}=$ the effect of algae type.

$D j=$ the effect of algae level.

$(T D)_{I J}=$ the effect of interaction

$e_{i j k}=$ random error

\section{RESULTS AND DISCUSSION}

\section{Water quality assessments}

Quality of water was checked every fortnight to determine $\mathrm{pH}$, ammonia $\left(\mathrm{NH}_{3}\right)$, nitrite-nitrogen $\left(\mathrm{NO}_{2}-\mathrm{N}\right)$ and nitrate- nitrogen $\left(\mathrm{NO}_{3}-\mathrm{N}\right)$. All measurements were carried out in the Limnology and Plankton Laboratories in the Department of Lim- nology of Central Laboratory for Agricultural Climate according to the standard methods of American Public Health Association (APHA, 1985) and Boyd (1990). Water temperature and oxygen saturation were measured daily at 8.00 am by an oxygen meter (Lutron model Do - 5509). Water quality was generally good in all tanks due to the continuous water replacement during the whole period. The $\mathrm{pH}$ values were measured in wastewater samples using a combined electrode connected to a $\mathrm{pH}$ meter (Coming Co. $\mathrm{pH}$ meter model 345). Ammonia-Nitrogen $\left(\mathrm{NH}^{+4}\right),\left(\mathrm{NH}_{3}\right)$, nitrate $\left(\mathrm{No}_{3}\right)$ were determined according to the methods described by Sauter and Stoub (1990). The water quality parameters were given in (Table 3 ) 

composition of Nile tilapia (Oreochromis niloticus)

Table 3. Averaged water quality determinations during the experimental period

\begin{tabular}{|l|c|}
\hline Parameter & Reading \\
\hline Average Temperature $\left(\mathrm{C}^{\circ}\right)$ & 26 \\
Oxygen (mg / L) & 6 \\
$\mathrm{pH}$ & 7.1 \\
Ammonia (mg / L) & 0.28 \\
Nitrite (mg / L) & 1 \\
\hline
\end{tabular}

\section{Growth performance and feeding utilization} parameters.

Data in Table (4) showed the growth performance of tilapia fingerlings fed different levels of both (Arthrospira platensis) Spirulina and Nannochloropsis gaditana algae. By increasing (Arthrospira platensis) Spirulina algae levels in fish diets from 3 to $7 \%$, growth performance of tilapia fish was reduced significantly $(P>0.05)$. the lowest significant $(P<0.05)$ average weight gain $(19.13 \mathrm{~g} /$ fish) was recorded by the group fed $7 \%$ (Arthrospira platensis) Spirulina (T4). Fish groups fed Nannochloropsis gaditana in diets showed no significant changes in the average weight gain. However, fish group fed 5\% Nannochloropsis gaditana (T6) showed the highest significant AWG. Results of Sarker et al (2018) showed no significant reduction in weight gain of tilapia fish when they added 3 and $5 \%$ Nannochloropsis gaditana in diets, whereas reduction in tilapia weight gain was observed with increasing Nannochloropsis gaditana levels higher than that. Also, Riveros et al (2018) found that supplemented Atlantic salmon diet up to 5\% Nannochloropsis gaditana diet had positive effect on its growth performance.

In the present research it was noticed that the highest ADG and SGR (Figure 1 \& 2) have been achieved by feeding tilapia fingerlings diets included nanno 5\%(T6), nanno 7\% (T7) respectively. Where the differences were significant $(P<0.05)$ among all treatments. Results in Table 4 showed that $5 \%$ and $7 \%$ Nannochloropsis gaditana, was greater than previous parameters. These results are supported by (Patterson et al 2013 and Tibaldi et al 2015) who demonstrated that dietary supplementation with various microalgae, including a related Nannochloropsis gaditana species up to $25 \%$ is acceptable based on growth performance, nutrient utilization, carcass yields, organ weights, sensory evaluation, digestive enzyme activities and intestinal histological parameters. So, the reason for the improvement in growth rates showed in nanno 5 may be explained by (Schneider and Roessler, 1994. Khozin- Goldberg \& Iskandarov, 2011) who reported that Nannochloropsis gaditana accumulates significant amounts of membrane-bound eicosapentaenoic acid (EPA). Apt and Behrens (1999) showed that Nannochloropsis gaditana species are widely used as aquafeed and have been proposed for the commercial production of EPA. The major fatty acids in Nannochloropsis gaditana are 14:0, 16:0, 20:4u்6 and 20:5ủ5

In the present study no mortality was observed in nanno7 and spiru 7 (Table 4 and Figure 3). Tilapia survival rates were not affected significantly $(P>0.05)$ by different feeding treatments. These findings agree with the result of Ben Hafsa et al. (2017) who reported that $N$. oculata are used widely in aquaculture for feeding and pathogens prevention. Isochrysis galbana and nannochloropsis oculata possessed important functional properties such as antioxidant, antimicrobial, anticholinesterase and antiproliferation activities, demonstrating the important value of these microalgae. The present results are also agree with Qureshi et al. (1996) who reported that (Arthrospira platensis) Spirulina could stimulate the immune system via increasing the phagocytic and the natural killer activities and with Bermejo et al. (2008) who reported that most antioxidant capacities of (Arthrospira platensis) Spirulina protein extract are attributable to the biliproteins contained in this microalga, such as phycocyanin so that we can use (Arthrospira platensis) Spirulina to improve the immunity capacity of the animals which consume it. 
Table 4. fish growth parameters fed different experimental diets

\begin{tabular}{|cccccccc|}
\hline $\begin{array}{c}\text { Treatments } \\
\text { Growth } \\
\text { parametes }\end{array}$ & Control & \multicolumn{3}{c}{ Spirulina } & \multicolumn{3}{c|}{ Nannochloropsis } \\
\cline { 2 - 8 } & $\mathbf{T 1}(\mathbf{0})$ & $\mathbf{T 2}(\mathbf{3})$ & $\mathbf{T 3}(\mathbf{5})$ & $\mathbf{T 4}(\mathbf{7})$ & $\mathbf{T 5}(\mathbf{3})$ & $\mathbf{T 6}(\mathbf{5})$ & $\mathbf{T 7}(\mathbf{7})$ \\
\hline IBW & $2.73 \pm 0.095$ & $2.46 \pm 0.066$ & $2.60 \pm 0.115$ & $2.73 \pm 0.240$ & $2.84 \pm 0.095$ & $2.80 \pm 0.166$ & $2.26 \pm 0.103$ \\
FBW & $25.63^{\mathrm{ab}} \pm 1.58$ & $24.7^{\mathrm{bc}} \pm 0.81$ & $24.22^{\mathrm{bc}} \pm 1.55$ & $21.86^{\mathrm{c}} \pm 0.26$ & $23.30^{\mathrm{bc}} \pm 1.80$ & $27.22^{\mathrm{a}} \pm 0.96$ & $23.82^{\mathrm{bc}} \pm 0.596$ \\
AWG & $22.75^{\mathrm{ab}} \pm 1.61$ & $22.27^{\mathrm{ab}} \pm 0.8$ & $21.50^{\mathrm{ab}} \pm 1.46$ & $19.13^{\mathrm{c}} \pm 0.40$ & $20.39^{\mathrm{ab}} \pm 1.84$ & $24.35^{\mathrm{a}} \pm 0.76$ & $21.55^{\mathrm{ab}} \pm 0.49$ \\
ADG & $0.23^{\mathrm{ab}} \pm 0.17$ & $0.234^{\mathrm{a}} \pm 0.17$ & $0.226^{\mathrm{ab}} \pm 0.17$ & $0.20^{\mathrm{b}} \pm 0.17$ & $0.21^{\mathrm{b}} \pm 0.17$ & $0.256^{\mathrm{a}} \pm 0.17$ & $0.22^{\mathrm{ab}} \pm 0.17$ \\
SGR & $2.22^{\mathrm{ab}} \pm 0.06$ & $2.32^{\mathrm{ab}} \pm 0.06$ & $2.22^{\mathrm{ab}} \pm 0.06$ & $2.12^{\mathrm{b}} \pm 0.06$ & $2.11^{\mathrm{b}} \pm 0.06$ & $2.29^{\mathrm{ab}} \pm 0.06$ & $2.40^{\mathrm{a}} \pm 0.06$ \\
SURVIVL & $97.7 \pm 1.00$ & $98.6 \pm 1.00$ & $96.9 \pm 1.00$ & $100 \pm 1.00$ & $99.4 \pm 1.00$ & $98.6 \pm 1.00$ & $100 \pm 1.00$ \\
\hline
\end{tabular}

Values are the mean \pm S.E. of triplicate groups.

Values in the same raw, with different superscripts are significantly different $(P<0.05)$. IBW: initial body weight; FBW: final body weight; AWG: average weight gain; ADG: average daily gain; SGR: specific growth rate; SR: survival rate.

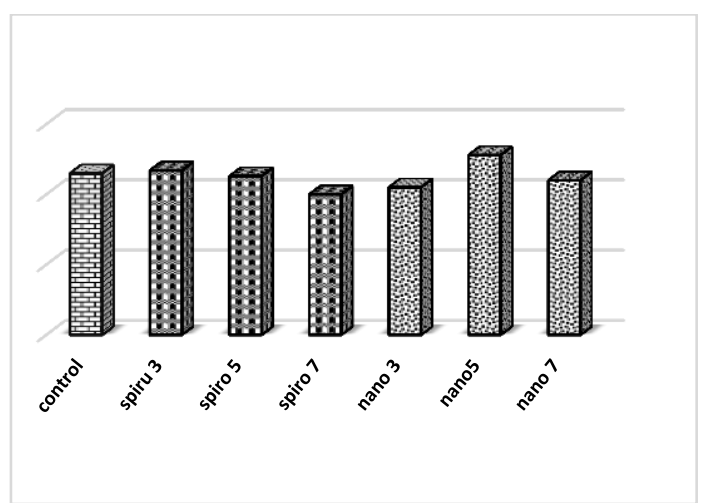

Fig. 1. ADG (glday/fish)of tilapia fish fed different types and level of algae

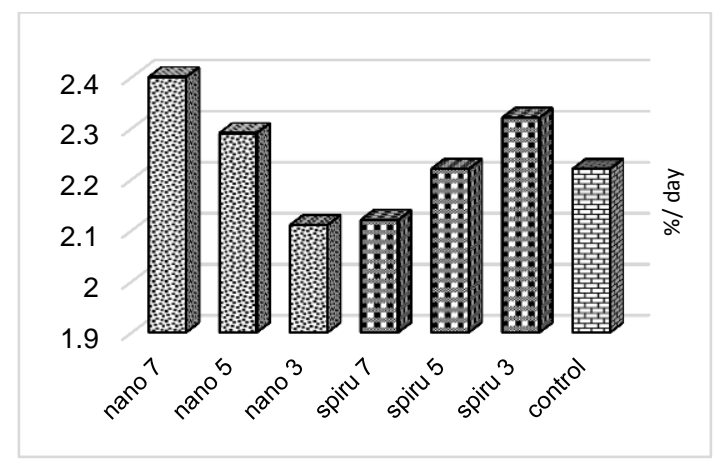

Fig. 2. SGR of tilapia fish fed different types and levels of algae

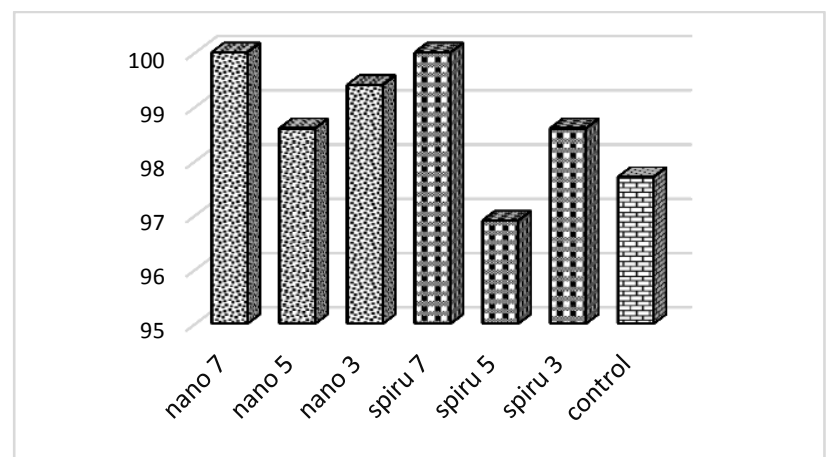

Fig. 3. Survival of tilapia fish fed different types and levels of algae

Results in Table (5) and Figures (4 and 5) show that the inclusion of different levels of Nannochloropsis gaditana and (Arthrospira platensis) Spirulina in tilapia diets had no significant effects $(P>0.05)$ on FCR. However, group fed diet 7\% (T7)
Nannochloropsis gaditana had the highest significant FER $(\mathrm{P}<0.05)$. No significant differences $(P>0.05)$ was observed between the other algae levels in FER. These may be due to that the levels of Nannochloropsis gaditana and (Arthrospira 

composition of Nile tilapia (Oreochromis niloticus)

platensis) Spirulina used in the present study were slightly lower than that required to achieve effects. These results are agreed with (Adel et al 2016), who found that dietary supplementation of Spirulina platensis up to $10 \%$ had no effects on growth performance, digestive enzyme activities, humoral and skin innate immune responses and disease resistance in the great sturgeon (Huso huso). Their results demonstrated that dietary supplementation with S. platensis (up to $10 \%$ level) could be useful for maintaining the overall health status of great sturgeon. Sørensen et al (2017) reported that feeds with $20 \%$ alga had negative effect on feed intake, FCR, lipid and energy retention and health of the fish. The defatted Nannochloropsis oceania can be used at modest inclusion levels, around $10 \%$, without negative effects on the performance of Atlantic salmon.

The PER and PPV\% results of the current research (Table 5 and Figures 6 and7) showed that by increasing the inclusion levels of (Arthrospira platensis) Spirulina, PER and PPV have been improved. The highest significant PER and PPV were obtained by adding 7\% (Arthrospira platensis) Spirulina or $7 \%$ Nannochloropsis gaditana in fish diets.

Table 5. Feed utilization parameters of tilapia fed different experimental diets

\begin{tabular}{|c|c|c|c|c|c|c|c|}
\hline \multirow[b]{2}{*}{ Feed utilization parameters } & \multirow{2}{*}{\begin{tabular}{|l|} 
Control \\
T1 (0) \\
\end{tabular}} & \multicolumn{3}{|l|}{ Spirulina } & \multicolumn{3}{|c|}{ Nannochloropsis } \\
\hline & & T2 (3) & T3 (5) & T4 (7) & T5 (3) & T6 (5) & T7(7) \\
\hline Feed Intake & $44.63^{\mathrm{ab}} \pm 0.924$ & $41.40^{\mathrm{bc}} \pm 0.23$ & $41.53^{b c} \pm 1.52$ & $39.06^{c} \pm 0.731$ & $41.0^{\mathrm{bc}} \pm 2.05$ & $46.66^{a} \pm 0.317$ & $40.6^{\mathrm{bc}} \pm 0.63$ \\
\hline FCR & $1.47 \pm 0.13$ & $1.38 \pm 0.13$ & $1.52 \pm 0.13$ & $1.77 \pm 0.13$ & $1.79 \pm 0.13$ & $1.42 \pm 0.13$ & $1.37 \pm 0.13$ \\
\hline FER & $0.71^{\mathrm{ab}} \pm 0.02$ & $0.73^{\mathrm{ab}} \pm 0.02$ & $0.71^{\mathrm{ab}} \pm 0.02$ & $0.67^{b} \pm 0.02$ & $0.68^{a b} \pm 0.02$ & $0.75^{\mathrm{ab}} \pm 0.02$ & $0.76^{\mathrm{a}} \pm 0.02$ \\
\hline PER & $2.72^{\mathrm{b}} \pm 0.003$ & $2.74^{\mathrm{ab}} \pm 0.01$ & $2.74^{\mathrm{ab}} \pm 0.00$ & $2.76^{\mathrm{a}} \pm 0.005$ & $2.73^{\mathrm{b}} \pm 0.008$ & $2.72^{\mathrm{b}} \pm 0.005$ & $2.72^{\mathrm{b}} \pm 0.00$ \\
\hline PPV & $19.07^{\mathrm{cd}} \pm 0.07$ & $20.80^{\mathrm{bc}} \pm 0.23$ & $20.74^{\mathrm{ab}} \pm 0.15$ & $20.0^{\mathrm{a}} \pm 0.084$ & $20.91^{\mathrm{ab}} \pm 0.219$ & $21.48^{\mathrm{d}} \pm 0.127$ & $22.90^{\mathrm{ab}} \pm 0.034$ \\
\hline
\end{tabular}

Values are the mean \pm S.E. of triplicate groups.

Values in the same raw, with different superscripts are significantly different $(P<0.05)$.

SR: survival rate; FCR: fed conversion ratio; PPV: protein productive value; and PER: protein efficiency ratio

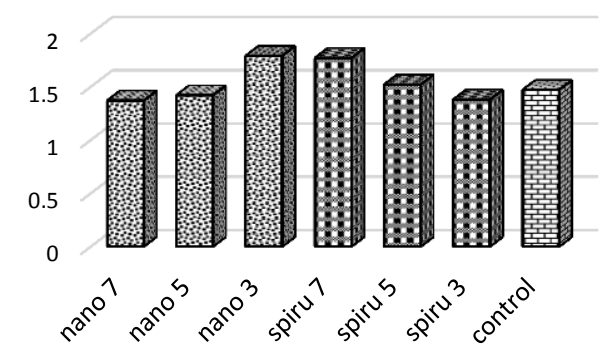

Fig. 4. FCR of tilapia fish fed different types and levels of algae

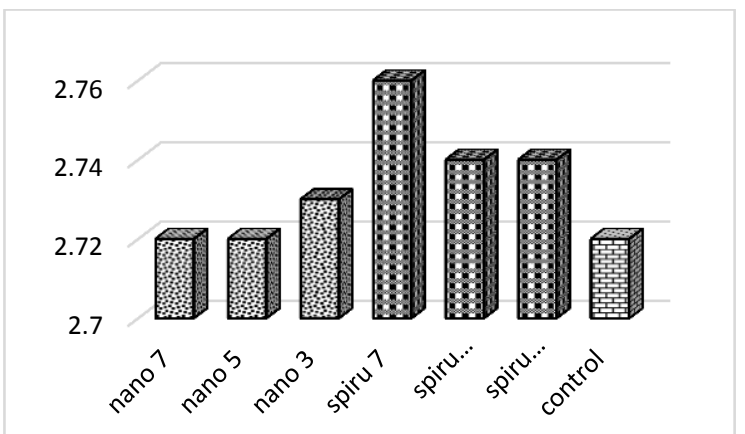

Fig. 6. PER of tilapia fish fed different types and levels of algae

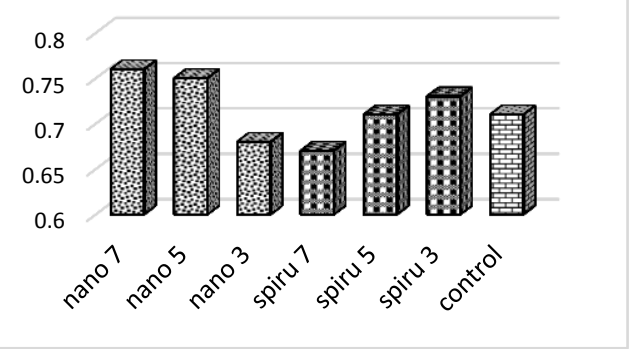

Fig. 5. FER of tilapia fish fed different types and levels of algae

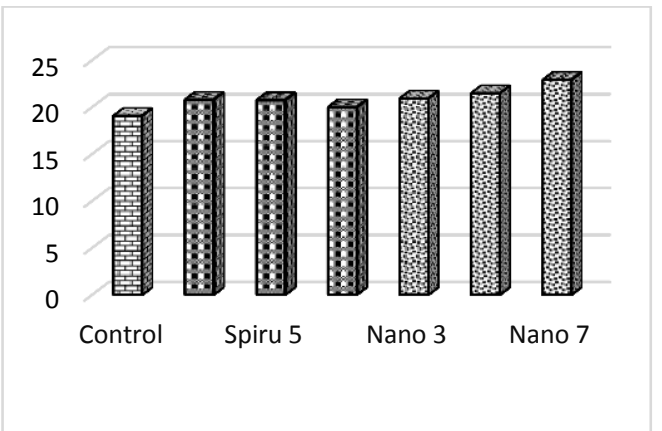

Fig. 7. PPV\% of tilapia fish fed different types and levels of algae 


\section{Chemical composition of fish carcass}

Chemical composition of the experimental fish was represented in Table (6). The results showed that treatments contain Nannochloropsis gaditana had the higher dry matter DM content. Protein content ranged between (55.8 to $61.25 \%$ ), the highest value was recorded by Nanno 7 (T7), while the lowest $(55.8 \%)$ was for the zero group. Also, it was noticed that $7 \%$ of both algae species (Arthrospira platensis) Spirulina and Nannochloropsis gaditana) improved protein content in fish body.

The highest lipid content was for Nanno7 (T6) (20.7\%) while the lowest value obtained by spiru 7 (T4) (16.3\%). On the other hand, fish in control group had the highest ash content $(21.35 \%)$ but nanno 5 (T6) had the lowest value (17.7\%).

These results were in contrary with Sørensen et al (2017) who reported that Neither the whole body, nor fillet proximate composition of Atlantic salmon was affected by the intake of Nannochloropsis gaditana except lipid content. Haas et al (2015) found that there is no significant different in body composition when they fed Atlantic salmon diets contained 50 and $100 \%$ Nannochloropsis gaditana replaced with fish oil. Sarker et al (2018) reported that Whole body proximate composition of Nile tilapia fillets did not significantly differ among dietary treatments when they replaced fish meal by $33 \%, 66 \%$ and $100 \%$ of Nannochloropsis oculate

Shearer (1994) reported that proximate composition varies with life stages of fish and is also influenced by endogenous factors such as genetics, size and sex, as well as exogenous factors such as feed composition, feeding frequency and environment.

Table 6. Chemical analysis of Nile tilapia fish (dry-basis) fed different experimental diets

\begin{tabular}{|cccccccc|}
\hline & Control & Spiru 3 & Spiru 5 & Spiru 7 & Nanno 3 & Nanno 5 & Nanno 7 \\
\hline DM & $22.1^{\mathrm{d}} \pm 0.08$ & $22.8^{\mathrm{c}} \pm 0.05$ & $22.8^{\mathrm{c}} \pm 0.05$ & $23.17^{\mathrm{c}} \pm 0.05$ & $24.5^{\mathrm{a}} \pm 0.05$ & $24.4^{\mathrm{a}} \pm 0.05$ & $24.1^{\mathrm{b}} \pm 0.05$ \\
CP & $57.58^{\mathrm{d}} \pm 0.05$ & $57.2^{\mathrm{e}} \pm 0.03$ & $59.1^{\mathrm{b}} \pm 0.06$ & $59.2^{\mathrm{b}} \pm 0.00$ & $58.4^{\mathrm{c}} \pm 0.05$ & $56.8^{\mathrm{f}} \pm 0.05$ & $61.25^{\mathrm{a}} \pm 0.02$ \\
EE & $17.8^{\mathrm{d}} \pm 0.003$ & $18.3^{\mathrm{c}} \pm 0.01$ & $17.8^{\mathrm{d}} \pm 0.01$ & $16.3^{\mathrm{f}} \pm 0.14$ & $17.2^{\mathrm{e}} \pm 0.01$ & $19.9^{\mathrm{b}} \pm 0.05$ & $20.7^{\mathrm{a}} \pm 0.11$ \\
\hline Ash & $21.35^{\mathrm{a}} \pm 0.08$ & $19.87^{\mathrm{c}} \pm 0.08$ & $18.9^{\mathrm{f}} \pm 0.05$ & $20.8^{\mathrm{b}} \pm 0.01$ & $19.18^{\mathrm{e}} \pm 0.01$ & $17.7^{\mathrm{g}} \pm 0.01$ & $19.4^{\mathrm{d}} \pm 0.005$ \\
\hline
\end{tabular}

$a, b$ means of the same raw with different superscript are significantly different $(p<0.05)$.

\section{CONCLUSION}

The results of the present study showed that adding algae ((Arthrospira platensis) Spirulina , or Nannochlorpsis) improved the productive performance of Tilapia fish under laboratory condition. More studies are still needed to approve the types, the optimum levels, the mode of action of each algae species and the interaction with the other environmental parameters in the field.

\section{REFERENCES}

Adel M., Yeganeh S., Dadar M., Sakai M. and Dawood, M.A.O., 2016. Effects of dietarySpirulina platensison growth performance, humoral and mucosal immune responses and disease resis-tance in juvenile great sturgeon (Huso huso Linnaeus, 1754). Fish \& Shellfish Immunology, 56, 436-444
A.O.A.C., 1975. Official Methods of Analysis, $12^{\text {th }}$ ed. Association of Official Analytical Chemists, Washington, DC., USA, pp. 69-88.

A.P.H.A. American Public Health Association, 1985. Standard methods for the examination of water and waste water $\left(16^{\text {th }}\right.$ ed. Washington, D.C., pp. 9-46.

Apt, K., and Behrens, P. W., 1999. Commercial development in microalgae biotechnology. J. Phycol. 35, 215-226

Ben Hafsa, M., Ben Ismail, M., Garrab, M., Aly, R., Gagnon, J. and Naghmouchi, K., 2017. antimicrobial, antioxidant, cytotoxic and anticholinesterase activities of water-soluble polysaccharides extracted from microalgae Isochrysis galbana and Nannochloropsis oculate. J. Serb. Chem. Soc. 82 (5), 509-522.

Bermejo, P., Piñero, E. and Villar, A., 2008. Ironchelating ability and antioxidant properties of phycocyanin isolated from a protean extract of 

composition of Nile tilapia (Oreochromis niloticus)

(Arthrospira platensis) Spirulina platensis. Food Chemistry, 110, 436-445.

Borowitzka, M.A., 1988. Microalgae as sources of pharmaceuticals and other biologically active compounds. J. Appl. Phyc., 4, 267-279.

Boyd, C.E., 1990. Water Quality in Ponds for Aquaculture. Birmingham Publishing, Birmingham, AL, 482 p.

Brown, MR., Jeffrey, S.W., Volkman, J.K. and Dunstan, G.A., 1997. Nutritional properties of microalgae for mariculture. Aquaculture 151, 315-331.

Cho, C.Y. and Kaushik S.J., 1985. Effects of protein intake on net metabiliable and net energy values of fish diets. In: Nutrition and feeding in fish, Academic Press, London, pp. 95- 117.

Cohen, Z., 1997. The chemicals of (Arthrospira platensis) Spirulina. In: A. Vonshak (Ed.), (Arthrospira platensis) Spirulina platensis (Arthrospira): Physiology, Cell-biology and Biotechnology. Taylor and Francis. London: pp. 175204.

Duncan, D.B., 1955. "Multiple range test and multiple F tests." Biometrics, 11 (1), 1-42.

Durmaz Y. 2007. Vitamin E (a-tocopherol) production by the marine microalgae Nannochloropsis oculata (Eustigmatophyceae) in nitrogen limitation. Aquaculture, 272, 717-722

Glombitza, K.W. and Koh, M., 1989. Secondary metabolites of pharmaceutical potentials. In: R.C. Cresswell, T.A.V. Rees and N. Shah (Eds.), Algal and Cyanobacterial Biotechnology. Logman, Harlow, UK: pp. 161-238.

Haas, S, Bauer, J.L. Adakli, A., Meyer, S., Lippemeier, S., Schwarz, K. and Schulz, C., 2015. Marine microalgae Pavlova viridis and Nannochloropsis sp. as n-3 PUFA source in diets for juvenile European sea bass (Dicentrarchus labrax L.). J. Appl. Phyco., 50, 223-237.

Hoffmann M., Marxen K., Schulz R., Vanselow K.H., 2010. TFA and EPA productivities of Nannochloropsis salina influenced by temperature and nitrate stimuli in turbidostatic controlled experiments. Mar. Drugs. 8, 25262545.

James CM, Al-Hinty and Salem, A.E., 1984. Growth and $\dot{\omega} 3$ fatty acids and amino acid composition of microalgae under different temperature regimes. Aquaculture 77, 337-351

Khozin-Goldberg, I., Iskandarov, U., Cohen, Z., 2011. LC-PUFA from photosynthetic microalgae: occurrence, biosynthesis, and prospects in biotechnology. App. Microbiol. Biotechnol. 91, 905-915.

Kim, S.S., Rahimnejad, S., Kim, K-W. and Lee, K.J., 2013. Partial replacement of fish meal with (Arthrospira platensis) Spirulina pacifica in diets for parrot fish (Oplegnathus fasciatus). Turkish Journal of Fish and Aquatic Sciences, 13, 197-204.

Kishimoto, M., Okakura, T., Nagashima, H., Minowa, T., Yakayama, S. and Yamaberi, K. 1994. $\mathrm{CO}_{2}$ fixation and oil production using $\mathrm{mi}-$ croalgae. J. Fermentation and Bioengineering, 78, 479-482.

Lin, W., Pan, B., Sheng, J., Xu, J. and Hu, Q., 2007. Antioxidant activity of (Arthrospira platensis) Spirulina platensis extracts by supercritical carbon dioxide extraction. Food Chemistry, 105, 36-41.

Ma Y.B., Wang Z.Y., Yu C.J., Yin Y.-H., Zhou G.K., 2014. Evaluation of the potential of 9 Nannochloropsis strains for biodiesel production. Bioresour. Technol., 167, 503-509.

Madhava, C., Bhat, V.B., Kiranmai, G., Reddy, M.N., Reddanna, P. and Madyastha, K.M., 2000. Selective inhibition of cyclooxygenase-2 by C-phycocyanin, a biliprotein from (Arthrospira platensis). Bioch. Biophys. Res. Comm., 277, 599-603.

Meyer-Burg-Dorf, K., Osman, M.F. and Guenther, K.D., 1989. Energy metabolism in Oreochromis niloticus. Aquaculture, 79, 283-291

NRC, 1993. Nutrient Requirement of Fish. National academy press, Washington, DC, USA, 124 p.

Ogbonda, K.H, Aminigo, R.E. and Abu, G.O., 2007. Influence of temperature and $\mathrm{pH}$ on biomass production and protein biosynthesis in putative Spirulina sp. Bioresources Technology 98 (11), 2207-2211

Patterson, D., Gatlin, D.M., 2013. Evaluation of whole and lipid-extracted algae meals in the diets of juvenile red drum (Sciaenops ocellatus), Aquaculture 416 (417), 92-98.

Qureshi, M.A. and Ali, R.A., 1996. Spirulina platensis exposure enhances macrophage phagocytic function in cats. Immunopharmacology and Immuno Toxicology, 18, 457463.

Qureshi, M.A., Kidd, M.T. and Ali, R.A., 1995. Spirulina platensis extract enhances chicken macrophage functions after in vitro exposure. J. Nutr. and Immunology, 3, 35-44.

Riveros K., Sepulveda C., Bazaes J., Marticoren P., Riquelme C. and Acién G., 2018. Overall development of a bioprocess for the outdoor 
production of Nannochloropsis gaditana for aquaculture. Aquaculture Research 49(1), 165176

Sarker P.K., Kapuscinski A.R., Bae A.Y., Donaldson E., Sitek A.J., Fitzgerald D.S., 2018. Towards sustainable aquafeeds: Evaluating substitution of fishmeal with lipid-extracted microalgal co-product (Nannochloropsis oculata) in diets of juvenile Nile tilapia (Oreochromis niloticus). PLoS ONE 13(7), e0201315. https://doi.org/10.1371/journal.pone.0201315

SAS, 2009. Statistical Analysis System, SAS User's Guide: $2^{\text {nd }}$ Ed. Statistics. SAS Institute Inc. Cary, NC, USA, pp. 120-150.

Sauter, A. and Stoub K., 1990. Official methods of analysis. Association of official analytical chemists, Inc. $5^{\text {Th }}$ Ed., Suite 400, ARLINGTON, Virginia 22201, USA, pp. 142-155.

Schneider, J. C., and Roessler, P., 1994. Radiolabeling studies of lipids and fatty acids in Nannochloropsis (Eustigmatophyceae), an oleaginousmarine alga. J. Phyc., 30, 594-598

Shearer K.D., 1994. Factors affecting the proximate composition of cultured fishes with emphasis on salmonids. Aquaculture. 119(1), 6388.

Sørensen, M., Gong, Y., Bjarnason, F., Vasanth, G.K., Dahle, D., Huntley, M., Kiron, V. 2017.
Nannochloropsis oceania-derived defatted meal as an alternative to fishmeal in Atlantic salmon feeds. PLoS ONE 12(7): e0179907. https://doi.org/ 10.1371/journal.pone.01799077

Steel, R.G.D. and Torrie, J.A., 1980. Principles and Procedures of Statistics. $2^{\text {nd }}$ Ed., USA McGraw Hill, pp.183-193.

Tibaldi, E., Zittelli, C.G., Parisi, G., Bruno, M., Giorgi, G. Tulli, F. Venturini, S. Tredici, M. R. Poli, B.M., 2015. Growth performance and quality traits of European sea bass (D. labrax) fed diets including increasing levels of freezedried Isochrysis $\mathrm{sp}$. (T-ISO) biomass as a source of protein and $n-3$ long chain PUFA in partial substitution of fish derivatives, Aquaculture 440, 60-68.

Vonshak, A., 1997. Appendics Spirulina platensis (Arthrospira): Physiology Cell-biology and Biotechnology. Taylor and Francis Ltd., London, 214 p.

Xiao-Nian Ma, Tian-Peng Chen, Bo Yang, Jin Liu, Feng Chen, 2016. Lipid Production From Nannochloropsis, Mar Drugs, 14(4), 61

Yaakob Z., Ehsan A., Afifi Z., Masita M. and Mohd S.T., 2014. An overview: biomolecules from microalgae for animal feed and aquaculture. J. Biological Research, Thessaloniki, 21, 6-23. 
المؤتمر الرابع عشر لبحوث التنمية الزراعية،

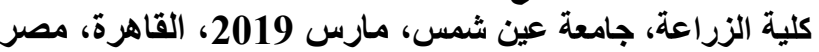

مجلا(27)، عدد (1)، عداعد خاص مارس، مارس

Website: http://strategy-plan.asu.edu.eg/AUJASCI/

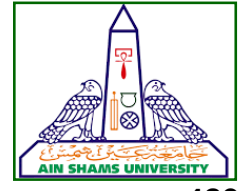

429

تأثير إضافة طحالب الاسبيرولينا وإناتوكلورويسيس على أداء النمو، كفاعة الاستفادة من الغذاء وتكوين الأبيحة لأسماك البأطي النيلي

[39]

\author{
زينب محمد علي عبدالعظيم- طارق أبوالمكارم علي- محمد فتحي عثمان

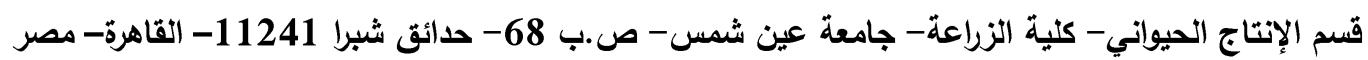

"Corresponding author: zeinab ma83@agr.asu.edu.eg

Received 8 October, 2018, $\quad$ Accepted 26 November, 2018

بشكل شبه ثابت خلا فترة التجربة. وكانت كثافة

الأسماك 15سمكة / حوض بوزن بداية متوسطه 2.7

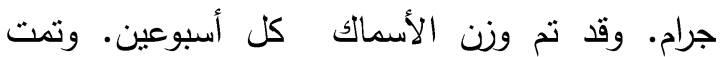
التغذية على عليقة 34\% بروتين لمدة 95 يوم. وقد ولد

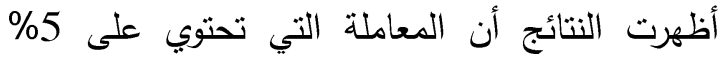

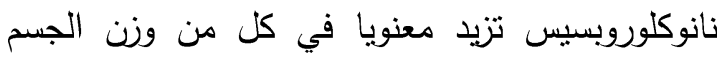
النهائي، متوسط الزيادة الوزنية ومعدل الزيادة الئادية اليومية

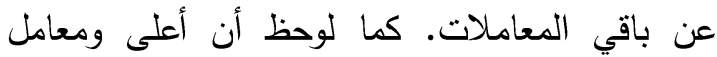

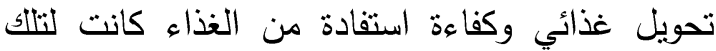

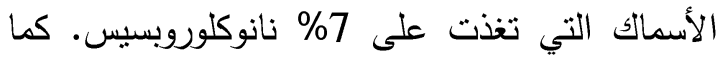

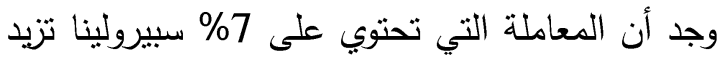

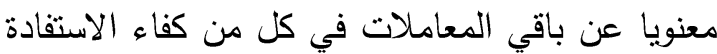

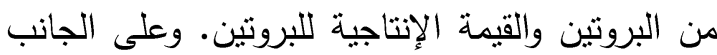

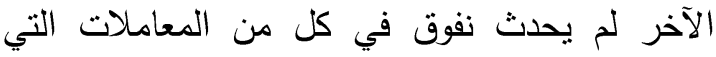
تحتوي 7\% من كل من الاسبيرولينا والنانوكلوربسيس. ويتضح من ذلك أن استخدام طحلب الاسبيرولينا

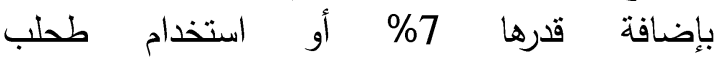
النانوكلوروبسيس بإضافة قدرها 5 \% \% يحسن الأداء الإنتاجي وكفاءة الاستفادة من الغذاء لأسماك البلطي النيلي.

الكلمات الدالة: الطحالب المجهرية - الاسبيرولينا النانوكلوروبسيس - الإضافات الغذائية

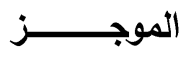

أجريت هذه الدراسة بكلية الزراعة جامعة عين شمس لتقييم تأثير إضافة نوعين من الطحالب المجهرية

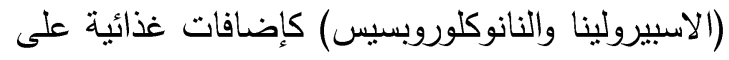

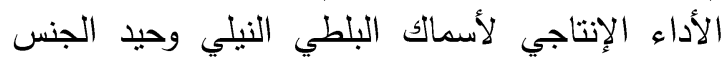

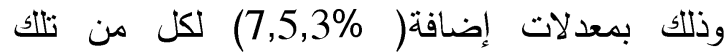

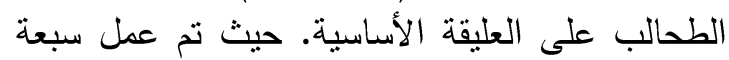
معاملات لكل معاملة ثلاث مكررات كالتالي:

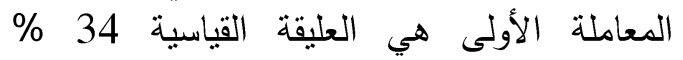
بروتين، والمعاملة الثانية هي العليقة الأساسية مضافا إليها 3\% سبيرولينا والمعاملة الثالثة عبارة عن العليقة

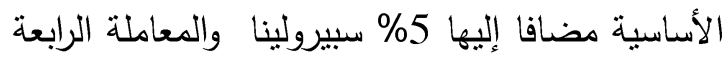
عبارة عن العليقة الأساسية مضافا إليها 7 \% سبيرولينا والمعاملة الخامسة عبارة عن العليقة الأساسية مضافاف العانة إليها 3\% نانوكلوروبسيس والمعاملة السادسة عبارة عن الإنة

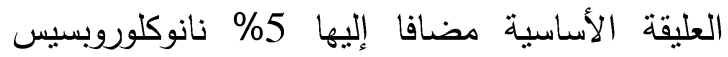

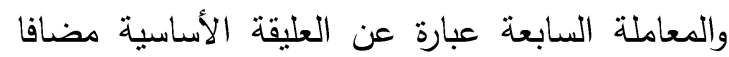
إليها7\% نانوكلوروبسيس. وأجريت التجربة في 21

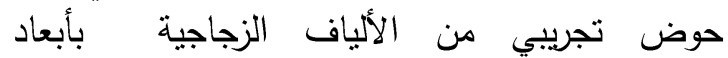

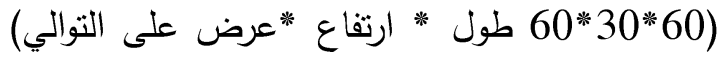
ملحق بنظام مغلق يتم فيه الحفاظ على الظروف الليئية

تحكيم: ا.د حمدي محمد أحمد السيد د. رانيا سعيد مبروك 